\title{
Relative effects of elevational and habitat constraints on alpine spring biodiversity
}

\author{
Cécile Claret $^{1}$ and Pierre Marmonier ${ }^{2, *}$ \\ ${ }^{1}$ Aix-Marseille Université, CNRS, IRD, Avignon Université, UMR-7263 IMBE, Institut Méditerranéen de Biodiversité et d'Écologie \\ Marine et Continentale, 13397 Marseille Cedex, France \\ ${ }^{2}$ Univ. Lyon, Université Claude Bernard Lyon 1, CNRS, ENTPE, UMR-5023 LEHNA, Laboratoire d'Écologie des Hydrosystèmes \\ Naturels et Anthropisés, 43 Boulevard du 11 Novembre 1918, 69622 Villeurbanne Cedex, France
}

Received: 13 June 2019; Accepted: 4 October 2019

\begin{abstract}
Global climatic changes and local disturbances may alter composition and distribution of spring invertebrates in mountains. In this study, we compared the effects of elevation, landscape and local characteristics on spring biodiversity. At 16 springs (from 570 to $1650 \mathrm{~m}$ a.s.1.) in The Chartreuse Range (French Alps) benthic, vegetation, and interstitial habitats were sampled in summer for aquatic invertebrate assemblage structure (abundances, richness, reproduction and dispersal traits, functional feeding groups). Assemblages were related to geographic location (elevation), landscape characteristics and local variables. Elevation was the major driver of the fauna: taxonomic richness and the percentage of scrapers decreased with elevation, while the proportion of predators and species with an asexual reproduction increased with elevation. The landscape characteristics around the spring had a weak influence on the benthic taxonomic richness which increased with the percentage of forest and decreased with the proportion of grassland. Finally, the habitat characteristics had no effect on taxonomic richness, but partially control the abundances of benthic assemblages and sediment-feeder organisms that both decreased with increasing sediment grain size. Current and future changes in the temperature patterns would affect alpine spring fauna, but disturbance of the local characteristics of springs must not be neglected.
\end{abstract}

Keywords: Alp mountains / ecotone / groundwater / land-cover / species traits

\section{Introduction}

Ecosystems at high altitudes are particularly sensitive to climate change and present thus particular challenges for biodiversity conservation (Walther et al., 2002; Elsen and Tingley, 2015; Allen and Lendemer, 2016). Climate changes trigger species distribution shifts in many parts of the world, but species from mountains are disproportionably sensitive to these changes (Thuiller et al., 2005; Dullinger et al., 2012). Range-restricted species, particularly mountaintop species, show severe range contractions and have been the first group in which entire species have gone extinct (Parmesan, 2006). Although not all climatic warming effects in mountain systems necessarily involve area reductions (Peterson, 2003). Upward shifts of species in high mountain systems are already observed. For example, the tree line and related human activities linked to forestry advance in response to environmental change (Grace et al., 2002) together with agriculture at

\footnotetext{
*Corresponding author: pierre.marmonier@univ-lyon1.fr
}

lower elevations. In the same way, similar shift was observed for river fauna (Hotaling et al., 2017). The distribution of species along the elevational gradient represents a stimulating model for the study of global climatic change on biodiversity and its consequences for conservation (Gaston, 2000).

Species richness is generally supposed to decrease along elevational gradients (Rapoport, 1982; Stevens, 1992) because the climatic constraints (temperature, duration of sub-zero temperatures) progressively exclude species on the basis of their biological and ecophysiological characteristics (e.g. for aquatic fauna Milner et al., 2001). More recently, the generality of a decrease in species richness with elevation was criticized (Kattan and Franco, 2004). In a review, Rahbek (1995) showed that decrease in species richness was not the rule and approximately half of the studies had a mid-elevation peak in species richness, because mountains may represent an attractive ecosystem for organisms. In most cases, studies of biodiversity patterns along elevation gradients focus on species richness or other global community variables, whereas groups of species based on their biological traits may follow very different elevation patterns (Gaston, 2000). Colwell and 
Lees (2000) insisted that resistance to dispersal or survival may explain elevational patterns and may be included in assemblage analyses. Biologic traits at the scale of the assemblages may represent an innovative way to study the elevational patterns in fauna and flora.

However, elevation is not a simple variable. There are two categories of environmental constraints that change with elevation (Kattan and Franco, 2004; Körner, 2007): (1) those directly linked to the physical elevation above the sea level, such as atmospheric pressure, oxygen partial pressure, UV inputs, and temperature that govern the large scale patterns that will be modified with global warming; and (2) those influenced by local scale characteristics, such as rainfall heterogeneity, soil and sediment characteristics, human activities and landuse (e.g. Castella et al., 2001; Milner et al., 2001; Forister et al., 2010; Death and Collier, 2010). Confounding the former by the latter will introduce confusion in the studies of elevational gradients, and detailed analysis of clines in local environmental variables needs to be combined with surveys of large scale biodiversity distribution (Lomolino, 2001).

Alpine springs perfectly fit with this double scale interaction, because they are ecotones between subterranean and superficial aquatic systems characterized by a mix of epigean and hypogean invertebrates (Vervier et al., 1992; Plénet et al., 1992; Botosaneanu, 1998). The conservation of this fauna needs disentangling the relative effects of global and local disturbances. In springs, ambient conditions, and especially water temperature, are clearly controlled by the mean elevation and temperature of the aquifer that fed the spring (Kamp, 1995), but the local geology and the surrounding landscape strongly modify the basic ecological properties of the ecotone (Vervier et al., 1992). The geological characteristics of the substratum for example controls the porosity of the rocks and the hydrodynamic of the springs (Plénet and Gibert, 1995; Zollhöfer et al., 2000), their stochasticity in dry climate (Rosati et al., 2017), whereas the bottom sediment grain size, the land-cover and the vegetation surrounding the spring may control the quantity and quality of the available organic matter (Stone and Wallace, 1998; Death and Collier, 2010; von Fumetti and Blattner, 2017). In contrast with rivers and streams, the colonization of alpine springs can only occur through upstream migration or flying adults. The species traits of spring fauna, such as ability to dispersal or reproduction strategies, may thus represent crucial characteristics that control the assemblage composition (Murphy et al., 2010; Rosati et al., 2017).

The aim of the present study was to assess the effect of elevational gradient, landscape, and local characteristics on the composition and structure of invertebrate assemblages at the interface between groundwater and surface water. We selected 16 springs in a karstic area (i.e. the Chartreuse Mountain Range in the French Alps), extending from 570 to $1650 \mathrm{~m}$ a.s.l. We examined abundance, taxonomic richness, diversity of the invertebrates in three habitats (benthic, vegetation, interstitial) as well as the effect of elevation on the proportion of three species traits in the assemblages: their ability to dispersal, their reproductive strategies, and their feeding preferences (i.e. five functional feeding groups). We hypothesised a strong effect of elevation on invertebrate assemblages (for abundances, species richness and diversity), because poorly mobile ectotherm invertebrates are limited by the temperature (Claret

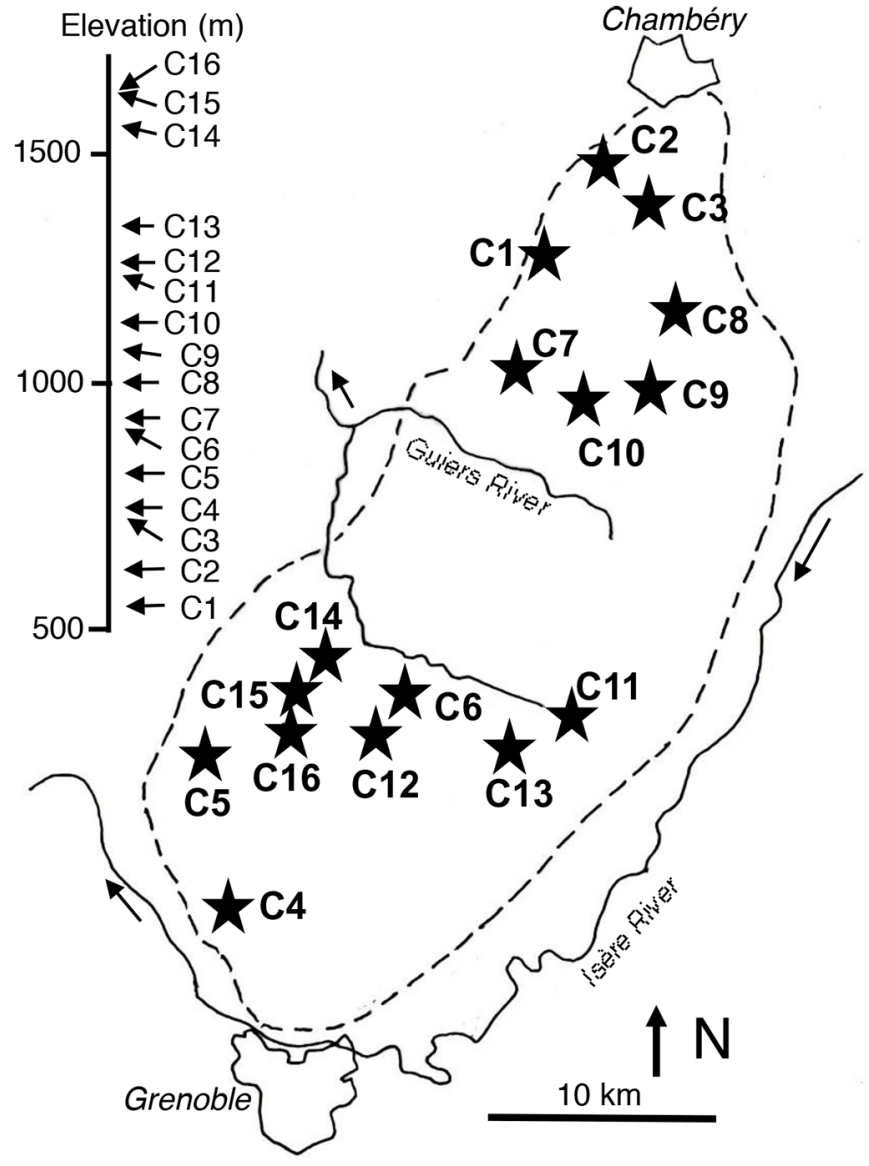

Fig. 1. Location of sampling sites in the Chartreuse Range, ranked according to their elevation.

et al., 1997; hypothesis 1). The colonization of isolated springs after drought or catastrophic snow melt will be directly controlled by the dispersal ability of species (Milner et al., 2001; Murphy et al., 2010) and their reproduction strategies (i.e. asexual species may found a population with a single individual). The proportion of organisms with high dispersal ability and asexual reproduction may thus increase with altitude (hypothesis 2). The vegetation characteristics of the surrounding landscape may also control the trophic characteristics of the organisms, with shredders more abundant in forested area and scrapers in springs surrounded by grassland (Stone and Wallace, 1998; Moore and Palmer, 2005; hypothesis 3) together with the local characteristics of the spring (grain size or water chemistry, Culp et al., 1983; Castella et al., 2001) may also control the abundances of some trophic groups (e.g. scrapers in coarse sediment and deposit feeders in sand; hypothesis 4).

\section{Methods}

The Chartreuse Range is a pre-alpine mountain chain located on the Western side of the French Alps between the cities of Grenoble and Chambery (Fig. 1). With an elevation that ranges from 250 to $2086 \mathrm{~m}$ a.s.l., the climate is wet $(\approx 2000 \mathrm{~mm}$ rainfall a year) and cold, with a mean annual 
Table 1. Characteristics of the springs sampled in the Chartreuse range.

\begin{tabular}{|c|c|c|c|c|c|c|c|c|c|c|c|c|c|}
\hline Station & Altitude & $\begin{array}{l}T \\
\left({ }^{\circ} \mathrm{C}\right)\end{array}$ & $\begin{array}{l}\text { Electric } \\
\text { conduct } \\
(\mu \mathrm{S} / \mathrm{cm})\end{array}$ & $\begin{array}{l}\mathrm{Cl} \\
(\mathrm{mg} / \mathrm{l})\end{array}$ & $\begin{array}{l}\mathrm{NO}_{3} \\
(\mathrm{mg} / \mathrm{l})\end{array}$ & $\begin{array}{l}\mathrm{SO}_{4} \\
(\mathrm{mg} / \mathrm{l})\end{array}$ & $\begin{array}{l}\text { Sediment } \\
\text { mean } \\
\text { diameter } \\
(\mathrm{mm})\end{array}$ & $\begin{array}{l}\text { Built } \\
(\%)\end{array}$ & $\begin{array}{l}\text { Roads } \\
(\%)\end{array}$ & $\begin{array}{l}\text { Fields } \\
(\%)\end{array}$ & $\begin{array}{l}\text { Grass } \\
\text { land } \\
(\%)\end{array}$ & $\begin{array}{l}\text { Forest } \\
(\%)\end{array}$ & $\begin{array}{l}\text { Rocks } \\
(\%)\end{array}$ \\
\hline $\mathrm{C} 1$ & 570 & 12.3 & 330 & 0.7 & 0.6 & 1.5 & 2 & 6.2 & 0.2 & 12.6 & 36.3 & 45.4 & 0.3 \\
\hline $\mathrm{C} 2$ & 620 & 10.7 & 498 & 1 & 1.5 & 5.9 & 2.7 & 2.6 & 0.1 & 10.6 & 50.5 & 36.2 & \\
\hline $\mathrm{C} 3$ & 710 & 9.6 & 605 & 3.4 & 3.9 & 14.3 & 2.2 & 1.3 & 0.1 & 8.1 & 71.7 & 18.8 & \\
\hline $\mathrm{C} 5$ & 830 & 8.2 & 308 & 0.6 & 2.4 & 3.5 & 2.2 & & 0.1 & & 1.8 & 97.2 & 0.9 \\
\hline C6 & 930 & 5.5 & 195 & 0.4 & 3.6 & 1.3 & 5 & & 0.1 & & 8.7 & 91.1 & \\
\hline $\mathrm{C} 7$ & 950 & 7.7 & 395 & 1.5 & 3.9 & 2.5 & 1.5 & & 0.1 & & 21.1 & 78.5 & 0.3 \\
\hline $\mathrm{C} 8$ & 1000 & 6.9 & 698 & 0.1 & 0 & 1.2 & 0.5 & & 0.1 & & 0.8 & 97.7 & 1.3 \\
\hline C9 & 1070 & 5.9 & 263 & 0.7 & 1.4 & 4.7 & 1.5 & 1.3 & 0.1 & 2.4 & 80.9 & 15.3 & \\
\hline $\mathrm{C} 10$ & 1155 & 12.9 & 340 & 0.4 & 0.2 & 0.9 & 0.1 & & & & 14 & 86 & \\
\hline $\mathrm{C} 15$ & 1650 & 6 & 341 & 0.5 & 1.1 & 4.3 & 2.7 & & & & 75.1 & 9.2 & 15.7 \\
\hline $\mathrm{C} 16$ & 1650 & 5.3 & 350 & 0.9 & 1.4 & 2.5 & 2 & & & & 40.7 & 26.2 & 39.1 \\
\hline
\end{tabular}

temperature of $9.1{ }^{\circ} \mathrm{C}$ (February mean $=-4.4{ }^{\circ} \mathrm{C}$; August mean $=17.3^{\circ} \mathrm{C}$ ) at Saint Pierre de Chartreuse ( $900 \mathrm{~m}$ a.s.1.). The number of days with snow ranged between 110 and 186 during the decade before the sampling period at the Col de Porte (1325 $\mathrm{m}$ a.s.1.). The geological substratum is essentially calcareous (from Oxfordian to Barremian) and medium-tohighly karstified. The dominant vegetation is a mixed forest of oak (Quercus spp.) and fir (Abies alba) at low elevation and of spruce (Picea abies) at intermediate and high elevations. Agriculture is primarily milk and wood production, which results in a mix of grasslands and forests in the landscape (i.e. $55.3 \%$ of forest and $21.5 \%$ of grassland at the Chartreuse scale; PNR de Chartreuse, 2005).

During July 1999, 16 springs were sampled (Tab. 1) from 570 to $1650 \mathrm{~m}$ a.s.1. At each spring, temperature and electric conductance were measured using a thermo-conductimeter (WTW LF 92) immersed directly in the spring water, with an additional surface water sample collected in a $100 \mathrm{ml}$ acidicwashed plastic bottle. At each spring, we measured the diameter of 100 randomly chosen particles $( \pm 1 \mathrm{~mm}$, Kellerhals and Bray, 1971). Mean particle sizes, with sand noted as $0.1 \mathrm{~mm}$ (Tab. 1) were calculated for each spring.

Fauna samples were collected from three different habitats. Benthic and vegetation habitats were sampled at three points in each using a mini-Surber net $(200 \mu \mathrm{m}$ mesh-net) on a surface of $0.033 \mathrm{~m}^{2}$ (total surface $0.1 \mathrm{~m}^{2}$ ). Interstitial fauna was sampled using the Karaman-Chapuis pit method: three pits of $15-20 \mathrm{~cm}$ deep and $20-30 \mathrm{~cm}$ width were dug in the emerged sediment on the border of the spring and a total of $5 \mathrm{~L}$ were sampled randomly combining the water of the three pits. Samples were preserved in the field in a $5 \%$ formaldehyde solution and stained with Bengal Pink.

In the laboratory, water samples were measured for chloride, nitrate, and sulphate concentrations $\left( \pm 0.1 \mathrm{mg} \mathrm{L}^{-1}\right)$ using a Capillary Ion Analyser (Waters, Milford, MA, U.S.A.).
Land-cover of the landscape surrounding each spring was estimated from aerial photographs, with the area of six landscape units (built area, roads, cultivated fields, grassland, forest, and rocks without vegetation). This landscape analysis was not performed for a watershed diagnosis but to document the local context of the springs. Landscape units were thus measured in a $1 \mathrm{~km}$ radial circle and expressed in percentage.

Invertebrates were sorted using sieves, identified to species, group of species, or genus level when allowed by individual size and available keys (Planaria, Acheta, Gastropoda, Bivalvia, Ostracoda, Cladocera, Amphipoda, Isopoda, Ephemeroptera, Trichoptera, Plecoptera, Coleoptera). Diptera were identified to the family level, the Copepoda were separated between Cyclopids and Harpacticids, the Nematoda, the Clitellata (Oligocheta), and the Hydracarian groups were not identified further. Three describers were calculated for each spring and each habitat: total abundance, taxonomic richness, Shannon diversity index $\left(\mathrm{H}^{\prime}\right)$. Three biological traits were documented for the invertebrate assemblages: (1) dispersal ability, divided in low dispersal species (without flying adults and only aquatic dispersal) or high dispersal species (with flying adults); (2) reproduction strategy, divided in exclusively sexual (separated sex) or potentially asexual (through body division or parthenogenesis); and (3) functional feeding groups, divided in shredders (chew conditioned litter or live vascular plant tissue or gouge wood), filtering collectors (suspension feeders - filter particles from the water column), deposit feeders (gathering collectors - ingest sediment or gather loose particles in depositional area), predators (capture and engulf prey or tissue, ingest body fluids) and scrapers (graze rock and wood surface or stems of rooted aquatic plants). Piercers and parasites were scarce or lacking and were not included in the analysis. Ecological traits of species were documented using the works of UsseglioPolatera et al. (2000) and synthetic tables from Tachet et al. 
Table 2. Characteristics of the assemblages sampled in the studied springs. Mean abundances ( \pm DS, $n=16)$. The midpoint altitude corresponds to the altitude where $50 \%$ of the individuals were caught (calculated from a cumulative curve).

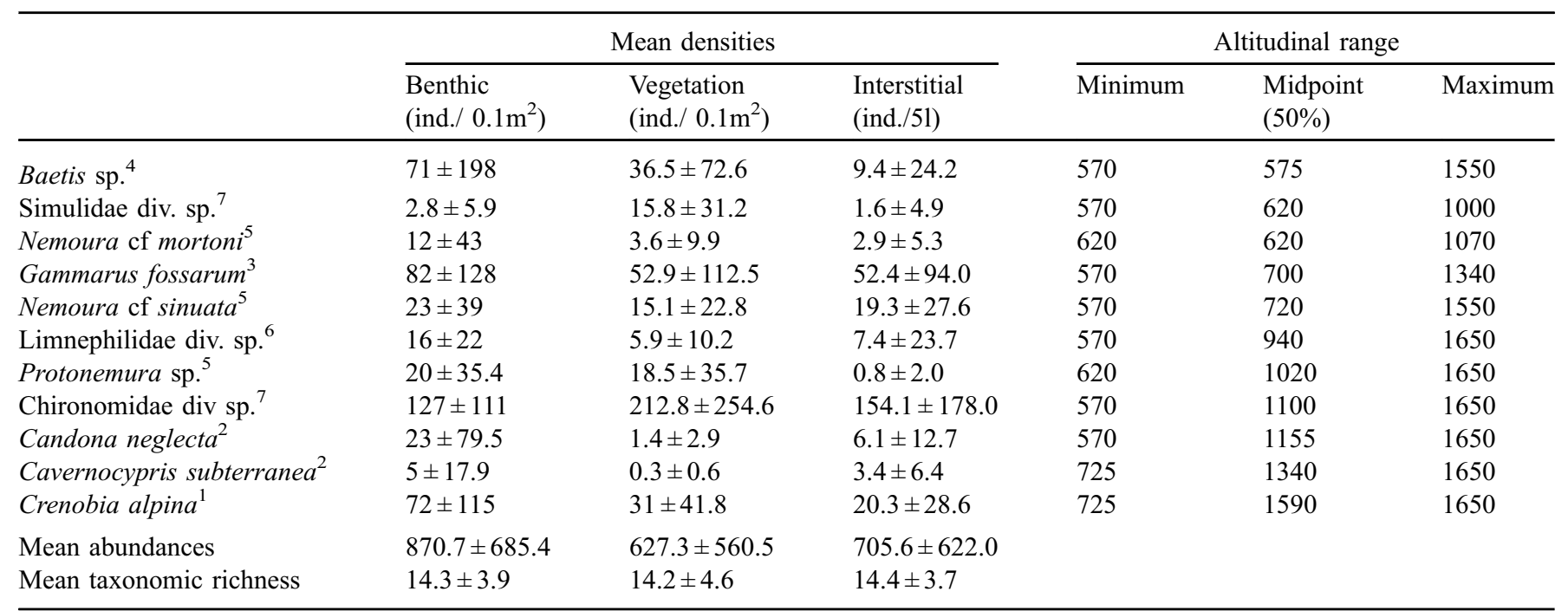

Taxonmic status: ${ }^{1}$ Planaria; ${ }^{2}$ Crustacea Ostracoda; ${ }^{3}$ Crustacea Amphipoda; ${ }^{4}$ Hexapoda Ephemeroptera; ${ }^{5}$ Hexapoda Plecoptera; ${ }^{6}$ Hexapoda Trichoptera; ${ }^{7}$ Hexapoda Diptera.

(2000). All percentages of feeding groups were calculated on abundances, when one taxon was affiliated to 2 or more functional groups, we applied a percentage of functional affinity in the abundance table according to its affinity to the different groups quoted in Tachet et al. (2000).

Patterns in the relationships between physical, chemical and landscape variables were revealed using Principal Components Analysis (PCA). The relationships between environmental variables and the assemblage characteristics (defined here above) were then examined by (1) including these assemblage characteristics as supplementary variables in a PCA performed on the environmental variables and (2) using linear regression models with the local physical characteristics and the landscape variables (following $\log _{x+1}$ transformation when necessary). The probability thresholds used in linear correlation and ANOVA were (as noted in the text): ${ }^{*}, P<$ 0.05 ; **,$P<0.01 ; * * *, P<0.001$. All tests were calculated using Statistica (8.0, StatSoft Inc., 2009, Tulsa, USA) or Excel 2016.

\section{Results}

A total of 13,931 invertebrate specimens, representing 46 taxa, were collected from benthic habitats, 10,036 individuals (41 taxa) from vegetation habitats, and 11,289 individuals (43 taxa) from interstitial habitats. Only two stygobite species (the Amphipoda Niphargus rhenorhodanensis (Schellenberg) and the Ostracoda Cavernocypris subterranea (Wolf)) were observed, having been collected at rather high elevation (until $1250 \mathrm{~m}$ for $N$. rhenorhodanensis and $1650 \mathrm{~m}$ a.s.l. for $C$. subterranea). The most diversified groups in these alpine springs were the Diptera (nine taxa), the Plecoptera (eight taxa), the Trichoptera (eight taxa), and the Ostracoda (six species), while the Ephemeroptera (four taxa), the Amphipoda (three species), and the Coleoptera (four taxa) poorly contributed to the total biodiversity. The most abundant organisms (Tab. 2) were all sampled in the three habitats, but showed contrasted elevational ranges.

\subsection{Elevation gradient and environmental parameters}

The first principal component axis (PC1), which accounted for $27.8 \%$ of the variation (Fig. 2), encompassed the elevation, the percentage of rocks, the mean diameter of the particles, the temperature, the electric conductance, the percentages of build area and cultivated fields. This first axis mostly represented thus an elevation gradient: the low elevation sites $(\mathrm{C} 1, \mathrm{C} 2, \mathrm{C} 3)$ had negative ordination scores, whereas high elevation sites $(\mathrm{C} 14, \mathrm{C} 15, \mathrm{C} 16)$ had positive scores. Whereas, PC2, which accounted for $23.6 \%$ of the variation, represented the human practice in the landscape surrounding the springs, including, the percentages of grassland (positive ordination scores) and of forest, roads, nitrate concentrations, and to a lesser extent mean diameter of the spring particles (negative scores). PC2 distinguished the mid-elevation site (site C9), located in grazed grassland, from those in managed forests with several unpaved roads for wood extraction (sites C4, C5, C6, C11). The dominance of elevation was apparent (Tab. 1), as it correlated positively with spring water temperature $\left(r^{2}=0.38\right.$, $P<0.01)$ and the percentage rocks $\left(r^{2}=0.60, P<0.001\right)$, and negatively with the percentages of built area $\left(r^{2}=0.31, P<\right.$ $0.05)$ and cultivated fields $\left(r^{2}=0.40, P<0.01\right)$. There were clear differences between areas devoted to milk or wood production, with the percentage of grassland negatively correlated to the percentage of forest $\left(r^{2}=0.94, P<0.001\right)$. Micro-habitat characteristics also contribute to PC2, sediment grain size and nitrate concentration had both negative ordination scores and were significantly correlated $\left(r^{2}=0.55, P<0.001\right)$, because nitrate concentrations were low in station with fine sediment (sites C8 and C10). 

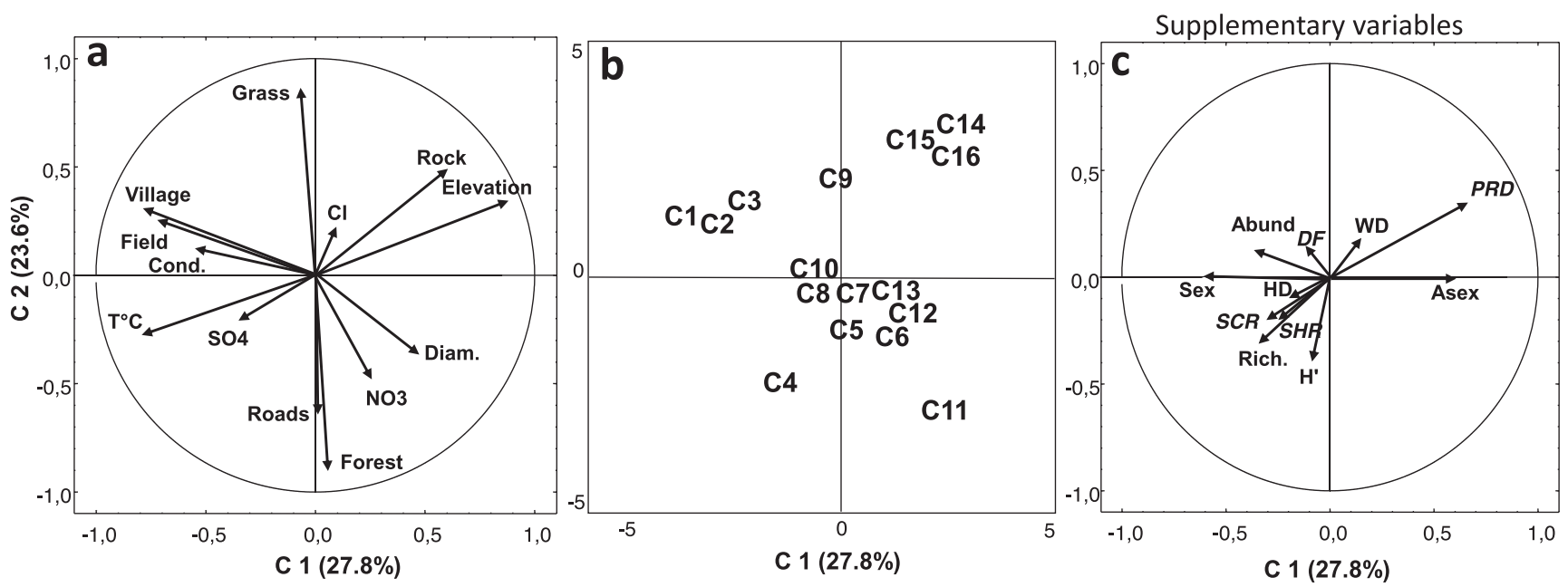

Fig. 2. Principal Component Analysis performed on the landscape and habitat characteristics of springs. (a) Relationships between the environmental variables (see Tab. 1 for abbreviation codes). (b) Location of sites in the $\mathrm{C} 1 \times \mathrm{C} 2$ plan. (c) Invertebrate assemblage characteristics added as supplementary material (Abund =abundances, Asex = percentage of species with a potential asexual reproduction, $\mathrm{DF}=\mathrm{deposit}$ feeders, $\mathrm{H}^{\prime}=$ Shannon diversity index, $\mathrm{HD}=$ percentage of species with a high dispersal ability, $\mathrm{PRD}=$ predators, Rich $=$ taxonomic richness, $\mathrm{SCR}=$ scrapers that fed on microphytes, $\mathrm{Sex}=$ species with an obligate sexual reproduction, $\mathrm{SHR}=$ shredders, $\mathrm{WD}=$ percentage of species with a weak dispersal ability).
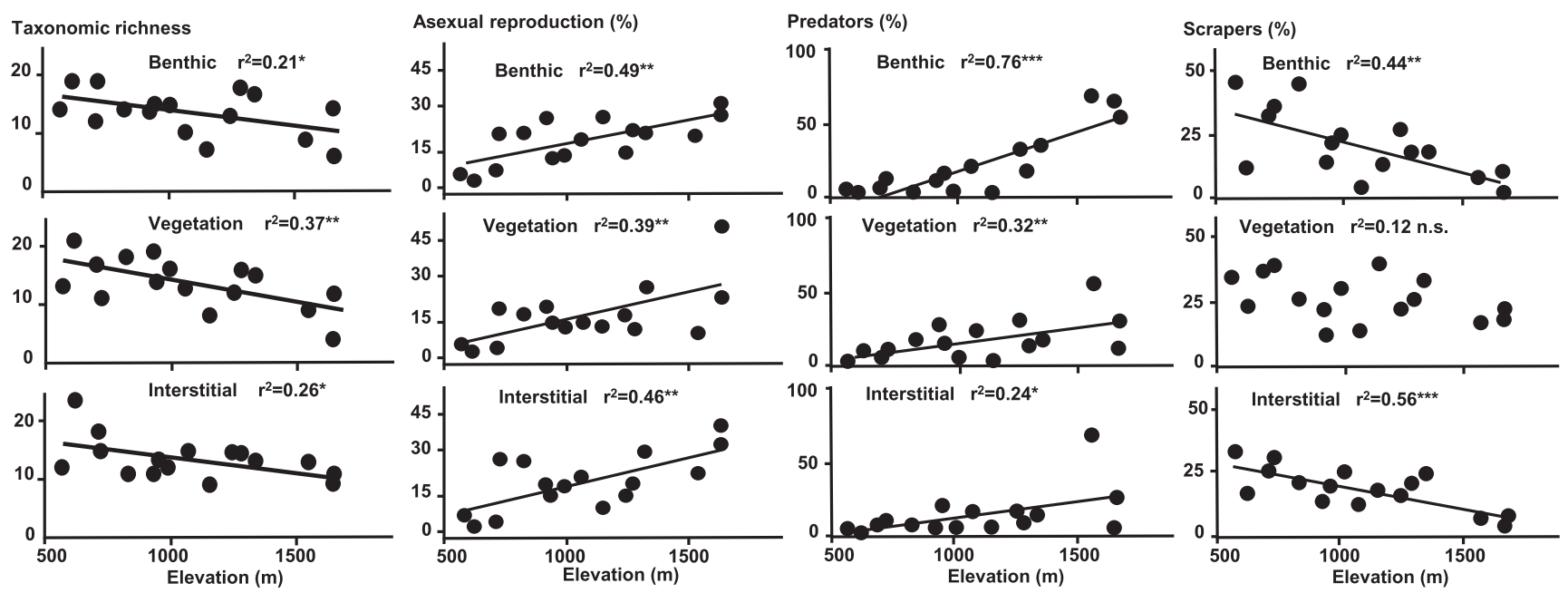

Fig. 3. Variation with elevation of taxonomic richness (a), with the proportion (\%) of species with potential asexual reproduction (b), and with the relative abundance of predators (c) and scrapers (d) in the benthic (upper panel), vegetation (middle panel), and interstitial habitats (lower panel).

\subsection{Elevation and invertebrate assemblages}

When assemblage characteristics were added as supplementary variables in the PCA performed on environmental variables (Fig. 2c) or plotted with elevation (Fig. 3), significant changes with elevation were observed but with contrasted trends. The abundances did not significantly change with elevation (supplementary material Fig. S1), but the taxonomic richness was clearly associated to the temperature (Fig. 2c) and negatively correlated with elevation in all three habitats (in all cases $P<0.05$; Fig. 3). The Shannon diversity index $\mathrm{H}^{\prime}$ decreased significantly with elevation in the vegetation habitat $\left(r^{2}=0.33, P<0.05\right)$, but not in the benthic and interstitial habitats (data not shown).

Similarly, the changes in the biological traits with elevation show contrasted trends. The dispersal characteristic did not change with elevation $(P>0.05)$, because of contrasted elevational trends between species without flying adults: Gammarus spp. decreased with elevation $\left(r^{2}=0.22, P<0.05\right)$, while Crenobia alpina significantly increased $\left(r^{2}=0.43, P<\right.$ 0.01 ). In contrast, the percentage of species with potential asexual reproduction were clearly associated to the elevation (positive ordination scores, Fig. $2 \mathrm{c}$ and significant correlations in all three habitats, $P<0.01$; Fig. 3 ). The species driving these 

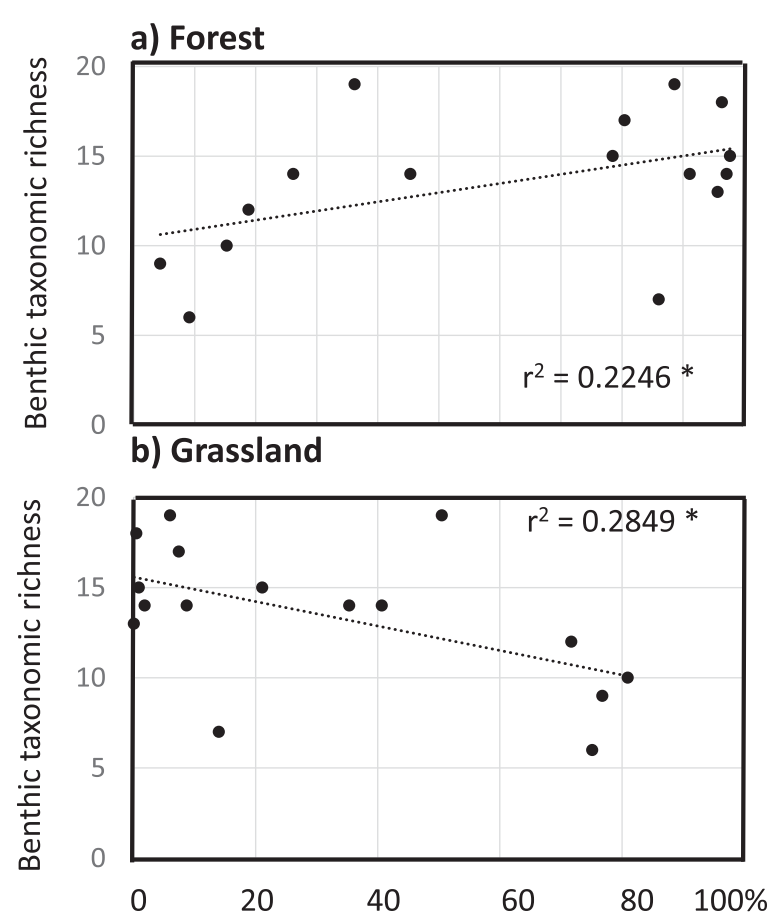

Fig. 4. Variation of benthic taxonomic richness with the percentage of forest (a) and the percentage of grassland (b) in a circular buffer of $1 \mathrm{~km}$ diameter around the spring. Linear regression models are $y=0.051 x+10.49$ for forest and $y=-0.067 x+15.58$ for grassland.

trends (Tab. 2) were the parthenogenic microcrustaceans (e.g. Cavernocypris subterranean, Potamocypris zschokkei) or the flatworm Crenobia alpina that can multiply asexually using body division.

The abundances of three feeding groups changed with elevation. The percentage of predators (mainly Crenobia alpina $)$ increased with elevation $(P<0.05$; Fig. 3$)$, while the percentage of scrapers decreased significantly with elevation in the benthic habitat $\left(r^{2}=0.44, P<0.01\right)$ and in the interstices $\left(r^{2}=0.56, P<0.001\right.$; Fig. 3). These scrapers consisted in insect larvae (e.g. Baetis sp., Agapetus sp.), micro-crustaceans (mostly Cladocera) or large crustaceans that use both coarse organic matter and microphytes (Gammarus fossarum Koch and G. wautieri Roux; Gayte and Fontvieille, 1997). Finally, the percentage of shredders decreased with elevation $\left(r^{2}=0.305, P<0.05\right)$, but only in the vegetation habitat (supplementary material Fig. S1)

\subsection{Landscape and habitat characteristics}

The surrounding landscape had a weak effect on the taxonomic richness and diversity of spring invertebrates for vegetation and interstitial habitat. Benthic richness slightly increased with increasing proportions of forest $\left(r^{2}=0.22, P<\right.$ 0.05 ; Fig. 4) and decreasing proportions of grassland around the spring $\left(r^{2}=0.28, P<0.05\right.$; Fig. 4 ; see supplementary material Fig. S2 for other land-cover). Six species of Plecoptera and 4 species of Ostracoda occurred together in stations $\mathrm{C} 11, \mathrm{C} 12$ and $\mathrm{C} 13$ surrounded by more than $80 \%$ of forest.

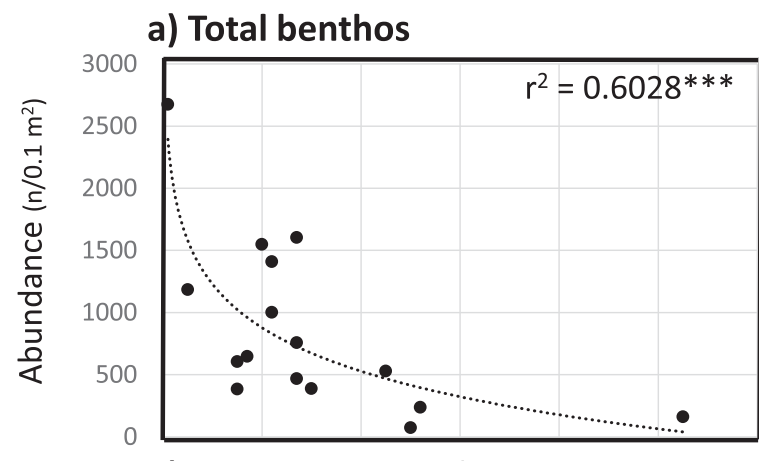

b) Benthic deposit feeder

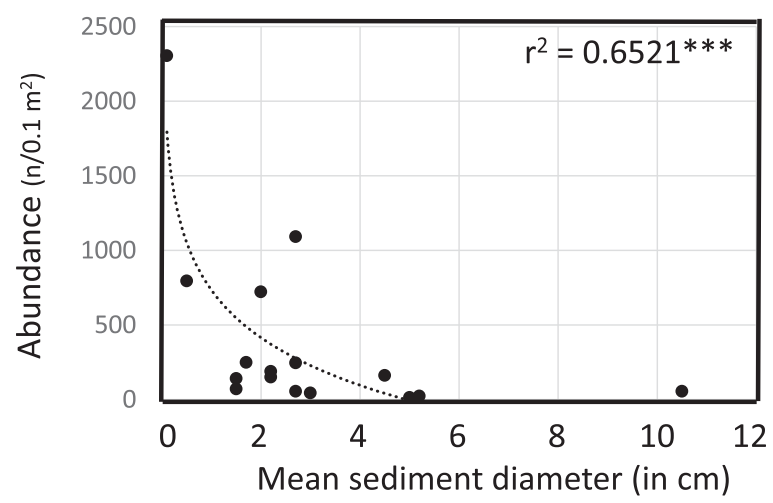

Fig. 5. Variation of benthic abundances (a) and benthic deposit feeder abundances (b) with sediment grain size. Regression models are $y=-505.7 \ln (x)+1228.8$ for the total benthic abundances and $y=-406.1 \ln (x)+733.34$ for deposit feeders.

The local characteristics of springs also had no effect on assemblage richness and Shannon diversity, but partially explained the abundances of the assemblages, especially in the benthic habitat. Benthic abundances (log transformed) decreased with the sediment grain size $\left(r^{2}=0.60, P<0.001\right.$; Fig. 5) because of deposit feeder abundances that were high in thin sediment $\left(r^{2}=0.65, P<0.001\right.$; Fig. 5 ; see supplementary material Fig. S3 for other feeding groups). The chemical characteristics of the spring water had no effect on species richness and diversity, but: nitrate concentrations were significantly and negatively correlated with benthic abundances $\left(r^{2}=0.234, P<0.05\right)$ and deposit feeder abundances $\left(r^{2}=0.301, P<0.05\right)$.

\section{Discussion}

\subsection{The effect of elevation on fauna diversity (hypothesis 1)}

In the alpine springs examined, species richness (in the three types of habitat) and the $\mathrm{H}^{\prime}$ diversity index (in the vegetation) decreased with elevation, whereas invertebrate abundances did not change with elevation. Our first hypothesis was thus only partially supported. This lack of change in abundances may be explained by a progressive replacement of a large number of low-elevation species (e.g. Nemoura spp., Gammarus spp.) by few species with a wide elevational range 
(e.g. Crenobia alpina), while the abundances of Clitellata and Chironomidae changed little.

The decreasing pattern in species richness with elevation was already well known for river fauna (e.g. Milner et al., 2001) but poorly documented for springs. This spatial pattern lend support to Rapoport's study (1982) where species average range size increases with increasing elevation, thus species with a narrow range are more likely to be found at lower elevations (Stevens, 1992). In this study, we did not observe species restricted to high elevation springs. Organisms particularly adapted to survive under harsh alpine conditions at high elevation are frequently signalled in alpine rivers, especially below glaciers (Khamis et al., 2014; Hotaling et al., 2017; Milner et al., 2017). Such endemic high mountain species may be found in area where springs are fed by glaciers instead of karstic groundwater like in the Chartreuse Range. Future study may include a set of springs located along a large elevational gradient covering from lowlands to glacial or permanent snow area.

The mountain springs are very small systems, the distance between them (and the resulting difficulties in colonization) may reinforce this decreasing gradient of taxonomic richness with elevation. In the present study, this observed elevational pattern in taxonomic richness was not influenced by human activities. In contrast, Chawla et al. (2008) observed that human impacts at lower elevations result in low plant diversity towards the bottom of the valley in western Himalaya. In our case, the very low surfaces occupied by villages and cultivated fields at low elevations explained the poor impact of agriculture on spring fauna. Despite this low impact of agriculture, the observed distribution of species along the elevational gradient was certainly already modified by human activities through global climatic changes that occurred during the decades before 1999 (Bruno et al., 2019; Hotaling et al., 2017). The gradient documented in this article is certainly already disturbed by climate modifications (Vittoz et al., 2013).

The environmental constraints that explain these changes with elevation need to be considered. The temperature of the spring water was certainly the most important constraints for the invertebrates together with other related variables such as the duration of the frozen period (not available for all studied springs). Several studies have highlighted the importance of temperature for population survival: for example, the reproduction of Gammarus roeseli Gervais is limited by thermal characteristics and the species is restricted to low elevations in the Austrian Alps (Pöckl, 1992). The occurrence of the hypogean Amphipoda, Niphargus rhenorhodanensis, in a spring at $1250 \mathrm{~m}$ a.s.l. may be surprising; these springs certainly froze during winter, and the subterranean organisms were supposed to live in thermally buffered biotopes. However, laboratory trials have demonstrated that $N$. rhenorhodanensis reared at sub-zero temperatures possess great thermal plasticity, which resulted in extended survival times (Issartel et al., 2005). These unexpected results can be explained by a large accumulation of cryoprotective molecules during cold acclimation, mainly membrane and protein protectants (Issartel et al., 2005). Their high tolerance to cold might be a relict adaptation which enabled their survival during glaciations and the nowadays colonization of high elevation springs (Colson-Proch et al., 2009).

\subsection{Species traits and elevation (hypothesis 2)}

Connection between springs decreases with elevation. For high elevation springs, their catchments are strongly isolated by deep valleys, but the predicted increased in invertebrate dispersal ability with elevation was not observed in this study (the hypothesis 2 is partially rejected). Abundances of organisms with winged adults decreased with elevation (Plecoptera, Ephemeroptera) or remained similar (Chironomidae). Similarly, abundances of taxa with low aquatic dispersal ability decreased (e.g. Gammarus fossarum) or increased (e.g. Crenobia alpina) with elevation and the proportion of micro-crustaceans that may be passively transported by wind (i.e. Ostracoda and Copepoda) did not significantly changed with elevation.

In contrast, the mode of reproduction clearly changed with elevation, with an increase in the percentage of species with potentially asexual reproduction (hypothesis 2 partly verified). The stygobite Ostracoda Cavernocypris subterranea is a good example of the constraint represented by the colonization of isolated springs at high elevation. This tiny crustacean is restricted to ground waters (in caves or porous aquifers) and the hyporheic zone of valley streams, and therefore unlikely to be translocated by birds or mammals. In springs, $C$. subterranea occurs in the benthic and vegetation habitats, sustained by the groundwater flux, which induces the drift of this animal outside the subterranean habitat and minimizes variations in surface water temperature and chemical composition. In these two superficial habitats, the probability of a transport of a single individual by a bird or a mammal strongly increased compared to groundwater habitat (Rogulj et al., 1994). For this species, the ability for an isolated individual to found a new population by asexual reproduction represents an important advantage, even with a reduced genetic diversity (e.g. for parthenogenetic Ostracoda, Butlin et al., 1998).

Predicted changes in the trophic groups with elevation was only verified for scrapers and predators. The relative abundances of scrapers decreased with elevation probably because algal growth is reduced at low temperature (Bothwell, 1988; Larras et al., 2013) even if insolation increases at high altitude. The percentage of predators was found to increase at high elevation in all three habitats. This latter pattern may be explained by the increase of a very few number of species. For example, Crenobia alpina represented $10-25 \%$ of individuals in springs between 1000 and $1500 \mathrm{~m}$ a.s.l. and $50-60 \%$ of individuals above $1500 \mathrm{~m}$. The study of the trophic links and the long term stability of such assemblage with $60 \%$ of predators may represent a stimulating topic for future research.

\subsection{The effects of landscape and local characteristics}

Several studies on river aquatic fauna from the Alps highlighted the importance of the combination between climatic changes and local environmental modifications, such as river regulation (Bruno et al., 2019), water pumping (Vittoz et al., 2013) or glacier loss (Khamis et al., 2014; Milner et al., 2017). In the studied alpine springs, the landscape characteristics had relatively little influence on invertebrate assemblage structure compared to the elevational gradient. For the landscape around the springs, we did not measure any 
significant decrease of shredder abundance or diversity with the decrease of forest or an increase of scrapers with the proportion of grassland as observed by Stone and Wallace (1998) in springs after clearcutting. The only trend observed concerned the benthic taxonomic richness that increased with the percentage of forest and decreased with the percentage of grassland. More than a stimulation of a single trophic group (e.g. the shredders), the increase in forest litter inputs may represent a resource for all taxa (as food, habitat or refuge) resulting in an increase of spring invertebrate richness.

Most of the local characteristics of the spring had no influence on taxonomic richness nor assemblage diversity, but sediment grain size and nitrate concentrations controlled the number of individuals present in the spring. The abundance of the benthic fauna increased with the proportion of thin sediment because of an increase in deposit feeder abundances, but decease with nitrate concentrations. Sandy bottom sediment of these springs was densely colonized by Clitellata and micro-crustaceans (a trend already observed in several small streams; Sarriquet et al., 2006; Jones et al., 2012), while nitrate concentrations decreased when groundwater flows through fine sediment due to denitrification (Lefebvre et al., 2005). In this case, the superficial processes control spring benthic assemblages more efficiently than groundwater characteristics (Plénet and Gibert, 1995) and must be documented in more detail (e.g. light intensity inside the spring, organic matter content of the sediment, denitrification, net primary productivity; Gaston, 2000) to understand the complex effects of local characteristics on invertebrate densities.

\subsection{Importance for biodiversity conservation}

In conclusion, the community composition of invertebrates in alpine springs is strongly controlled by the elevational gradient and will be modified by current and future climatic changes. The benthic fauna of alpine rivers in the southern Alps changed between 1970 and 2010 (with modification in the proportions of psychrophilic and thermophilic organisms; Bruno et al., 2019), but no data were available for alpine springs. The present study highlighted the dominance of the elevational gradient compared to the local and landscape characteristics of the springs. Future changes in the temperature patterns over mountainous regions are, therefore, likely to have a much greater effect on spring fauna than local management actions to protect spring biodiversity.

The protection of alpine spring (e.g. with a fenced area around the spring) is a frequent proposed management, because it prevents the direct access of cattle to the spring and resulting bottom sediment disturbance (e.g. inputs organic matter). The role of sediment grain size in the control of invertebrate assemblages was highlighted by several studies in a large range of aquatic systems (e.g. Culp et al., 1983), certainly because grain size is a synthetic variable that accounts for the habitability of the bottom sediment (Boulton et al., 1998), the type of organic matter stored (fine detritus versus algae; Corkum, 1996), and the maximum velocity of water that shapes grain size profiles. The link between sediment grain size and benthic abundances observed in this study highlights the potential role of local disturbance in spring biodiversity dynamics and supports that local management must be carefully considered.

The observed predominance of elevation over other local constraints illustrates the importance of temperature and related variables in determining spring biodiversity. The current and future climatic changes will induce modifications in mean aquifer temperature and thus in the distribution of invertebrate species along elevation gradients. Some rangerestricted species (such as Crenobia alpina) may be endangered with upward shift of mobile and aggressive species (e.g. Gammarus spp.) now restricted to lower elevations. Climate changes may also induce modifications in mountain human activities at low elevations that may induce in turn changes in the diversity of spring assemblages.

\section{Supplementary material}

Table S1 and Figures S1 to S3.

The Supplementary Material is available at https://www. limnology-journal.org/10.1051/limn/2019021/olm.

Acknowledgements. We thank the Regional Natural Park of the Chartreuse (M. Delamette and M. Frachisse) for valuable information on the Chartreuse mountains, G.H. Copp (CEFAS, Lowestoft, UK) for editing the English text, S. Gaudon and the students of the University of Savoie for their investment in field sampling, M.J. Dole-Olivier and M. Creuzé des Châtelliers (CNRS - University Lyon 1) and several members of the ZABR (LTSER of the Rhône Basin) for valuable discussion.

\section{References}

Allen JL, Lendemer JC. 2016. Climate change impacts on endemic, high-elevation lichens in a biodiversity hotspot. Biodivers Conserv 25: 555-568.

Boulton AJ, Findlay S, Marmonier P, Stanley EH, Vallet HM. 1998. The functional significance of the hyporheic zone in streams and rivers. Ann Rev Ecol Syst 29: 59-81.

Bothwell ML. 1988. Growth rate responses of lotic periphytic diatoms to experimental phosphorus enrichment: the influence of temperature and light. Can J Fish Aquat Sci 45: 261-270.

Botosaneanu L. 1998. Studies in Crenobiology. The Biology of springs and springbrooks. Leiden: Backhuys Publisher, $261 \mathrm{p}$.

Bruno D, Belmar O, Maire A, Morel A, Dumont B, Datry T. 2019. Structural and functional responses of invertebrate communities to climate change and flow regulation in alpine catchments. Glob Chang Biol 25: 1612-1628.

Butlin R, Schön I, Martens K. 1998. Asexual reproduction in nonmarine ostracods. Heredity 81: 473-480.

Castella E, Adalsteinsson H, Brittain JE, et al. 2001. Macrobenthic invertebrate richness and composition along a latitudinal gradient of European glacier-fed streams. Freshw Biol 46: 1811-1831.

Chawla A, Rajkumar S, Singh KN, Lal B, Singh RD, Thukral AK. 2008. Plant species diversity along an altitudinal gradient of Bhabha Valley in western Himalaya. J Mater Sci 5: 157-177.

Claret C, Marmonier P, Lescher-Moutoue F. 1997. Premier inventaire de la faune de sources karstiques et limnocrènes du massif de la Vanoise. Trav Sci Parc Nat Vanoise 20: 153-171. 
Colson-Proch C, Renault D, Gravot A, Douady CJ, Hervant F. 2009. Do current environmental conditions explain physiological and metabolic responses of subterranean crustaceans to cold? $J$ Exp Biol 212: 1859-1868.

Corkum LD. 1996. Responses of chlorophyll-a, organic matter, and macroinvertebrates to nutrient additions in rivers flowing through agricultural and forested land. Arch Hydrobiol 136: 391-411.

Culp JM, Walde SJ, Davies RW. 1983. Relative importance of substrate particle size and detritus to stream benthic macroinvertebrate microdistribution. Can J Fish Aquat Sci 40: 1568-1574.

Death RG, Collier KJ. 2010. Measuring stream macroinvertebrate responses to gradients of vegetation cover: when is enough enough? Freshw Biol 55: 1447-1464.

Dullinger S, Gattringer A, Thuiller W, et al. 2012. Extinction debt of high-mountain plants under twenty-first-century climate change. Nat Clim Change 2: 619-622.

Elsen PR, Tingley MW. 2015. Global mountain topography and the fate of montane species under climate change. Nat Clim Change 5: $772-777$.

Forister ML, McCall AC, Sanders NJ, et al. 2010. Compounded effects of climate change and habitat alteration shift patterns of butterfly diversity. Proc Natl Acad Sci USA 107: 2088-2092.

Gaston KJ. 2000. Global patterns in biodiversity. Nature 405: 220 227.

Gayte X, Fontvieille D. 1997. Autochthonous vs. allochthonous organic matter ingested by a macroinvertebrate in headwater streams: Gammarus sp. as a biological probe. Arch Hydrobiol 140: 23-36.

Grace J, Berninger F, Nagy L. 2002. Impacts of climatic change on the tree line. Ann Bot-Londin 90: 537-544.

Hotaling S, Finn DS, Joseph Giersch J, Weisrock DW, Jacobsen D. 2017. Climate change and alpine stream biology: progress, challenges, and opportunities for the future. Biol Rev 92: 20242045.

Issartel J, Renault D, Voituron Y, Bouchereau A, Vernon P, Hervant F. 2005. Metabolic responses to cold in subterranean crustaceans. J Exp Biol 208: 2923-2929.

Jones JI, Murphy JF, Collins AL, Sear DA, Naden PS, Armitage PD. 2012. The impact of fine sediment on macro-invertebrates. River Res Appl 28: 1055-1071.

Kamp GV. 1995. The hydrology of springs in relation to the biodiversity of spring fauna: a review. J Kansas Entomol Soc 68: 4-17.

Kattan GH, Franco P. 2004. Bird diversity along elevational gradients in the Andes of Colombia: area and mass effects. Global Ecol Biogeogr 13: 451-456.

Kellerhals R, Bray DI. 1971. Sampling procedures for coarse fluvial sediments. J Hydraul Div ASCE 97: 1165-1180.

Khamis K, Hannah DM, Brown LE, Tiberti R, Milner AM. 2014. The use of invertebrates as indicators of environmental change in alpine rivers and lakes. Sci Total Environ 493: 1242-1254.

Körner C. 2007. The use of 'altitude' in ecological research. Trends Ecol Evol 11: 569-574.

Larras F, Lambert AS, Pesce S, Rimet F, Bouchez A, Montuelle B. 2013. The effect of temperature and a herbicide mixture on freshwater periphytic algae. Ecotox Environ Saf 98: 162-170.

Lefebvre S, Marmonier P, Pinay G, Bour O, Aquilina L, Baudry J. 2005. Nutrient dynamics in interstitial habitats of low-order rural streams with different bedrock geology (granite versus schist). Arch Hydrobiol 164: 169-191.

Lomolino MV. 2001. Elevation gradients of species-density: historical and prospective views. Glob Ecol Biogeogr 10: 3-13.
Milner AM, Brittain JE, Castella E, Petts GE. 2001. Trends of macroinvertebrate community structure in glacier-fed rivers in relation to environmental conditions: a synthesis. Freshw Biol 46: $1833-1847$.

Milner AM, Khamis K, Battin TJ, et al. 2017. Glacier shrinkage driving global changes in downstream systems. Proc Natl Acad Sci USA 114: 9770-9778.

Moore AA, Palmer MA. 2005. Invertebrate biodiversity in agricultural and urban headwater streams: implications for conservation and management. Ecol Appl 15: 1169-1177.

Murphy NP, Guzik MT, Wilmer JW. 2010. The influence of landscape on population structure of four invertebrates in groundwater springs. Freshw Biol 55: 2499-2509.

Parmesan C. 2006. Ecological and evolutionary responses to recent climate change. Annu Rev Ecol Evolution Syst 37: 637-669.

Peterson AT. 2003. Projected climate change effects on Rocky mountain and Great Plains birds: generalities of biodiversity consequences. Glob Change Biol 9: 647-655.

Plénet S, Gibert J. 1995. Comparison of surface water/groundwater interface zones in fluvial and karstic systems. C R Acad Sci Paris III-Vie 318: 499-509.

Plénet S, Gibert J, Vervier P. 1992. A floodplain spring: an ecotone between surface water and groundwater. Regul River 7: 93-102.

PNR de Chartreuse. 2005. Révision de la charte du Parc Naturel Regional de Chartreuse. Diagnostic de territoir. PNR Chartreuse Publ., 173 p.

Pöckl M. 1992. Effects of temperature, age and body size on moulting and growth in the freshwater amphipods Gammarus fossarum and G. roeseli. Freshw Biol 27: 211-225.

Rahbek C. 1995. The elevation gradient of species richness: a uniform pattern? Ecography 18: 200-205.

Rapoport EH. 1982. Aerography: geographical strategies of species. New York: Pergamon Press, 286 p.

Rogulj B, Marmonier P, Danielopol DL, Lattinger R. 1994. Fine-scale distribution of hypogean Ostracoda in the interstitial habitats of the Rivers Sava and Rhône. Hydrobiologia 287: 19-28.

Rosati M, Rossetti G, Cantonati M, Pieri V, Roca JR, Mesquita-Joanes F. 2017. Are aquatic assemblages from small water bodies more stochastic in dryer climates? An analysis of ostracod spring metacommunities. Hydrobiologia 793: 199-212.

Sarriquet PE, Delettre YR, Marmonier P. 2006. Effects of catchment disturbance on stream invertebrates: comparison of different habitats (vegetation, benthic and interstitial) using bio-ecological groups. Int J Limnol 42: 205-219.

StatSoft Inc. 2009. STATISTICA (data analysis software system), version 8.0. Tulsa, OK: StatSoft, Inc.

Stevens GC. 1992. The elevational gradient in altitudinal range: an extension of Rapoport's latitudinal rule to altitude. Am Nat 140: 893-911.

Stone MK, Wallace JB. 1998. Long-term recovery of mountain stream from clear-cut logging: the effects of forest succession on benthic invertebrate community structure. Freshw Biol 39: 151-169.

Tachet H, Richoux P, Bournaud M, Usseglio-Polatera P. 2000. Invertébrés d'eau douce : systématique, biologie, écologie. CNRS Editions, Paris, 605 p.

Thuiller W, Lavorel S, Arauio MB, Sykes MT, Prentice IC. 2005. Climate change threats to plant diversity in Europe. Proc Natl Acad Sci USA 102: 8245-8250.

Usseglio-Polatera P, Bournaud M, Richoux P, Tachet $\mathrm{H}$. 2000. Biological and ecological traits of benthic freshwater 
macroinvertebrates: relationships and definition of groups with similar traits. Freshw Biol 43: 175-205.

Vervier P, Gibert J, Marmonier P, Dole-Olivier MJ. 1992. Perspective on permeability of surface freshwater/groundwater ecotone. J North Am Benthol Soc 11: 93-102.

Vittoz P, Cherix D, Gonseth Y, et al. 2013. Climate change impacts on biodiversity in Switzerland: A review. J Nat Conserv 21: 154-162. von Fumetti S, Blattner L. 2017. Faunistic assemblages of natural springs in different areas in the Swiss National Park: a small-scale comparison. Hydrobiologia 793: 175-184.

Walther GR, Post E, Convey P, et al. 2002. Ecological responses to recent climate change. Nature 416: 398-395.

Zollhöfer JM, Brunke M, Gonser T. 2000. A typology of springs in Switzerland by integrating habitat variables and fauna. Archiv Hydrobiol 121: 349-376.

Cite this article as: Claret C, Marmonier P. 2019. Relative effects of elevational and habitat constraints on alpine spring biodiversity. Ann. Limnol. - Int. J. Lim. 55: 20. 